\title{
Morality is its own Reward
}

\author{
E. SONNY ELIZONDO \\ University of California, Santa Barbara \\ Email: eselizondo@philosophy.ucsb.edu
}

\begin{abstract}
Traditionally, Kantian ethics has been thought hostile to agents' well-being. Recent commentators have rightly called this thought into question, but they do not push their challenge far enough. For they assume, in line with the tradition, that happiness is all there is to well-being - an assumption which, combined with Kant's rationalism about morality and empiricism about happiness, implies that morality and well-being are at best extrinsically related. Drawing on Kant's underappreciated discussion of self-contentment, an intellectual analogue of happiness, I reconstruct an alternative account of morality's relation to well-being. Morality is intrinsically related to well-being - and so is its own reward - not because it makes us happy but because it makes us self-contented.
\end{abstract}

Keywords: morality, happiness, well-being, self-contentment

It has seemed to many a condition on the correct ethical theory that it plausibly connect morality to the sources of human well-being. Those who have insisted on this condition have tended, in the main, to be ill-disposed towards Kant. One important reason for this disposition is the apparent difficulty Kant has in fitting morality and happiness together in a single human life. The traditional and by now familiar story goes something like this. The concerns of morality - duty, reason, respect - are so different from the concerns of happiness - interest, inclination, pleasure - that reconciliation between the two is impossible. We can be moral, or we can be happy, but we cannot, save for supernatural assistance, be both. ${ }^{\mathrm{I}}$

Though still influential, this traditional reading of Kant no longer predominates, at least not among serious interpreters. Indeed, much of the best recent work on Kant's ethics makes a powerful case that a morally good life, in moderately favourable circumstances, will be anything but miserable. Not only does morality leave us ample room to pursue our happiness, or at least the permissible parts of it. It also allows and even 
insists that our happiness itself be transformed, so that, in general, the same activities that make us good also make us happy. ${ }^{2}$

Details aside, this work constitutes a significant step forward for Kantian ethics: we can, under the right conditions, be both moral and happy. That said, I worry that even this modern form of Kantianism fails to provide everything one might reasonably want in an account of morality's connection to well-being. In particular, though the modern Kantians allow us to live well and to live morally, they do not - or at least do not obviously allow us to live well in living morally, in the sense that morality is in and of itself a source of well-being, something that makes our lives go well. The reason is that the modern Kantians, no less than their traditional forebears, tend to make two important assumptions: first, that happiness is all there is to well-being; and second, that while morality is a rational business, an activity of (practical) intellect, happiness is an empirical one, a state of sensibility. Taken together, these assumptions imply that morality's relation to well-being is entirely extrinsic. Since morality can only make our lives go well by making us happy, and since morality can only make us happy by influencing our sensibility, morality is not its own reward - not really. It is simply the condition for some separate benefit.

Now, while there is little question that Kant accepts the second of the above assumptions - that morality is rational and happiness empirical I think there is good reason to doubt that he accepts the first - that well-being is exhausted by happiness. Consequently, it is open to Kant to claim that morality makes our lives go well but not by making us happy. And so, I think, he does, in his discussion of a condition he calls 'self-contentment', 'an analogue of happiness that must necessarily accompany consciousness of virtue' (KpV, 5 : I I 7$).^{3}$

The significance of self-contentment has been largely overlooked, and not without reason. Kant says little about this condition, at least in his canonical works, and what he does say is in various ways problematic. Nonetheless, Kantian theory provides resources for working out a more adequate account of self-contentment, resources that Kant himself could have deployed but did not. My aim in this article, then, is to draw out these resources and to develop such an account, one that makes plain how and why self-contentment is uniquely suited to serve as a bridge between morality and well-being.

More specifically, I will advance and defend two main claims. First, properly understood, well-being is a genus with two species: one 
sensible - happiness - and one intellectual - self-contentment. Thus since humans are both sensible and intellectual beings, their well-being includes both happiness and self-contentment. Second, self-contentment, unlike happiness, is essentially moral. Thus while morality can only be extrinsically related to happiness, it can be, and indeed is, intrinsically related to self-contentment and thereby to well-being. If this is right, then morality and well-being are more intimately related than even Kant's most sympathetic interpreters have thought. For though there is more to living well than living morally - self-contentment is only part of our well-being, not the whole of it - morality is nonetheless its own reward.

1

I begin by examining Kant's conception of happiness. This is not an easy task, as Kant's explicit comments on happiness are scattered, relatively brief and, superficially at least, difficult to reconcile with one another and with other aspects of his work. Nonetheless, it is possible to discern the outlines of a unified account, one that suggests a more complicated relation between well-being and happiness than is usually supposed.

I count (at least) three different views of happiness in Kant, each privileging a different condition: satisfaction of the inclinations, pleasure and well-being. The first view understands happiness as the sum of the satisfaction of inclinations $(K r V, \mathrm{~A} 800 / \mathrm{B} 828, \mathrm{~A} 806 / \mathrm{B} 834 ; G, 4: 399$, 405). The second view understands happiness as some sort of good feeling, pleasure or, as Kant often says, agreeableness $(K p V, 5: 22, K U, 5$ : 208). The third view understands happiness as well-being or welfare, what makes an agent's life go well for her $(G, 4: 393,4$ I 8$) .{ }^{4}$

Kant does not explicitly distinguish these views of happiness. He moves back and forth between them without any acknowledgement that they are or even might be different. But they clearly are different. For example, getting what you want and feeling pleased - even when you are pleased because you have gotten what you want - are simply different things. The one depends on the fit between your psychology and the world; the other depends, in the first instance at least, on your psychology alone. As for well-being, it is not entirely clear what Kant has in mind here. On the one hand, one could construe the view formally: an agent is happy when her life goes well for her, whatever that comes to. On the other hand, one could construe the view substantively: an agent is happy when her life goes well for her, and her life goes well for her when she ... The formal construal is consistent with a variety of different accounts of well-being and so happiness, while the substantive construal is not. On neither 
construal, though, is the third view identical to the first or second, if only because these views make no obvious claim about what makes an agent's life go well for her.

However, Kant's easy equivalence between these views of happiness gives some reason to think that, in characterizing happiness in terms of the satisfaction of inclination or pleasure, he does take himself to be characterizing what makes an agent's life go well for her. This suggests that the third view, at least on the formal construal, is consistent with the first two views; these views are simply fuller accounts of what makes a life go well.

But not all of Kant's comments about well-being support the formal construal. Kant often seems to have something quite particular in mind when he speaks of well-being. For example, in the second Critique, Kant explicitly distinguishes good $(G u t)$ and well-being (Wohl). Good concerns, in the first instance, objects of the will, towards which reason directs us, while well-being concerns the feeling of agreeableness, which Kant clearly identifies with sensible pleasure $(K p V, 5: 60, K U$ 5: 205, $A, 7: 230)$. Such comments seem to support a substantive rather than formal construal of well-being: an agent is happy when her life goes well for her, and her life goes well for her when she is pleased. Moreover, if this construal is correct, then Kant in fact has only two different views of happiness: happiness as the satisfaction of inclinations and happiness as agreeableness. The inclusion of the concept of well-being would still add something to Kant's account - it would add that views of happiness are also views of what makes a life go well for an agent - but it would not provide any genuine rival to the other two views.

Kant does not, however, always identify well-being with agreeableness. Indeed, in the Dialectic of the second Critique, Kant clearly, if not explicitly, denies just this identification. For there he defines beatitude, or blessedness, as a 'complete well-being (Wohl) independent of all contingent causes in the world' (KpV, 5: $\mathrm{I} 23)$. This definition is important, since Kant is clear that there is only one being in the world (or even beyond it) who is truly blessed, and that is God (KpV, 5: I3I, VpR, 28: I089-9I). But notice: on Kant's traditional view of divinity, divine nature excludes anything sensible; since God cannot be affected by anything - not even himself - he has no sensibility and so, a fortiori, no sensible pleasures (VpR, 28: ${ }_{105} \mathrm{I}, \mathrm{KrV}$, B 7I). ${ }^{5}$ Thus if God possesses blessedness, and so well-being, but lacks sensibility, then well-being cannot be identified with agreeableness. It must be something more general, something that can be intelligibly applied to both divine and human beings alike. 
This requirement might seem to favour the formal construal of well-being, since on this construal it is easy to see how Kant's account of well-being could meet the requirement. So long as both God and humans have lives that can go well, it will make sense to speak of well-being in both cases. That said, I want to explore the possibility that Kant actually does accept a substantive construal of well-being, one that applies both to God and to us.

Such exploration will require attention to Kant's theological views. This might seem an unusual and unpromising tack to take. The problem is not merely that appeals to divine nature seem prima facie suspect, especially for someone like Kant, for whom rational theology is a paradigm of corrupt metaphysics. It is also that, whatever epistemic reservations we have about theology, we can be fairly confident that if there is a God, he is quite different from us - so different in fact that significant assertions of continuity are bound to seem dubious.

Though not unreasonable, these considerations should not deter us from making use of Kant's theology. Though Kant denies that we have theoretical cognition of God, he does not deny that we can think constructively about God. Indeed, he thinks we can say quite a lot about divine nature without thereby committing ourselves to divine existence. That is, we can confidently make statements of the form: if there were a God, he would have to be like this ... ${ }^{6}$ Kant clearly extends such conditional assertions to the case of divine psychology. His method is to draw on our understanding of our own faculties and extrapolate from there, by cancelling the limitations to which our psychology is subject $(\mathrm{VpR}, 28$ : I048). For example, Kant regards it as a limitation of our cognitive faculty that our understanding can apprehend particulars only through the use of concepts. Thus God's understanding, which must be unlimited, is not discursive but intuitive ( $\mathrm{VpR}, 28$ : I050). As Kant sees it, then, the same mental kinds can be attributed to God and to us. It is just that in the divine case the instantiations of these kinds are perfect and in our case they are not. So long as we are attentive to these differences, there seems to be no barrier to using one species of mind to illuminate another.

Moreover, adverting to Kant's theological views in such contexts is not merely something we can do. It is something we should do. After all, Kant is clear that the first, though by no means only, topic of practical philosophy is rational nature as such and not merely its human instantiation. Marking this distinction, however, is likely to be a challenge, so long as the only example of rational nature we have is our 
own. But if Kant is right that we can think constructively about God, then we are not so restricted. For in the case of God, we have an example of pure rational nature: a clean case, so to speak, that we can then use to shed light on the messier case of human beings, to disentangle what properly belongs to reason and what has its origin elsewhere.

While one might readily accept the relevance of such analogies to our understanding of morality, which is obviously rational, one might well be more sceptical of their relevance to our understanding of well-being, which Kant clearly associates with happiness and so, it seems, with sensibility. It is precisely this scepticism, however, that I mean to question. There is surely something about well-being that is merely sensible. But the fact that Kant attributes well-being to God suggests that the simple identification of well-being with sensibility cannot be right. Just as morality has a root in reason, so too may well-being, at least in part. Such a connection is likely to remain obscure so long as one attends only to Kant's discussion of human beings. Adverting to Kant's discussion of God might therefore provide a valuable corrective.

\section{2}

Kant gives some indication of a substantive construal of well-being, one that applies both to God and to us, in the second Critique. Consider his claim that

to be happy is necessarily the demand of every rational but finite being and therefore an unavoidable determining ground of its faculty of desire. For, satisfaction (Zufriedenheit) with one's whole existence is not, as it were, an original possession and a beatitude, which would presuppose a consciousness of one's independent self-sufficiency, but is instead a problem imposed upon him by his finite nature itself, because he is needy ... (KpV , $5: 25)$

Kant's thought here is somewhat obscure, but the key notion is clearly 'satisfaction with one's whole existence', which is plainly meant to stand in for happiness. ${ }^{7}$ Kant does not explain what he means by satisfaction with one's whole existence. He often associates satisfaction with pleasure, and given his previous definition of happiness in terms of agreeableness, this is exactly what one would expect. Satisfaction with one's existence is a kind of pervasive good feeling or, as he at one point puts it, 'a rational being's consciousness of the agreeableness of life uninterruptedly accompanying his whole existence' $(K p V, 5: 22)$. 
We should not be so quick to endorse this interpretation of satisfaction, however, since some of what Kant says here seems inconsistent with it. For example, he claims that satisfaction with one's whole existence is not, for a finite being, a 'beatitude' or 'original possession' but 'a problem imposed upon him by his finite nature itself' $(K p V, 5: 25)$. This claim seems to presuppose that an infinite being can be, and indeed is, satisfied with its whole existence originally, that is, by nature. And since, as we saw earlier, Kant thinks that an infinite being does not possess sensible feelings, he cannot think that satisfaction with one's existence is simply a matter of agreeableness. It must be something more.

We find a clue to the nature of satisfaction in another translation of the German word Zufriedenheit. Instead of satisfaction with one's whole existence, we can speak of contentment with one's whole existence. ${ }^{8}$ This alternative invites a different interpretation of satisfaction than that considered above. For example, in calling someone contented we seem to be suggesting not, or not necessarily, that she feels any particular pleasure. Rather, we are suggesting that she is motivated to remain in her current condition and, in this sense, is satisfied with it. Consider the contentment of a good meal, after which one simply sits back comfortably in one's chair, not because one cannot move - though perhaps one cannot: the Thanksgiving problem - but because one has no impulse to do so. One might, in such a moment, feel some pleasure, but such pleasure does not, I think, make for contentment. It is a distinct, if frequently co-occurring, element of such circumstances.

Making out Kant's claim in terms of contentment seems consonant with the use to which he subsequently puts the concept of satisfaction with one's whole existence. Recall Kant's claim that satisfaction - hereafter, contentment - with one's whole existence is a 'problem imposed upon [the human being] by his finite nature itself, because he is needy' $(K p V, 5$ : 25). How might the presence of need present a problem for our contentment, understood in the above terms? In order to answer this question, we must first understand better what Kant means by 'need'.

There is a common-sense notion of need that restricts needs to necessities. I need something if I cannot, in some strong sense, do without it. In the absence of the needed thing, I will suffer some significant harm or fail to achieve some necessary purpose or something of the sort. Genuine needs thus contrast sharply with mere wants. I genuinely need food, but I merely want an HDTV. Without food, I will die. Without an HDTV, I will simply have to forgo the pleasure of peering into the newsman's pores. 
Now Kant does have a notion of need that is in this way restrictive. He calls such needs 'true needs', and he includes among these whatever is necessary to maintain our rational capacities. But Kant also seems to have a more general, more promiscuous notion of need, and I think it is this notion that is dominant in the current discussion. ${ }^{9}$ This notion of need maintains some connection to necessities, but the necessity is not of the sort exemplified by true needs. Absence of the needed thing does not have to result in significant harm or the like. All it must result in is some measure of discontentment with one's existence. So, for example, though I will not suffer significant harm in the absence of an HDTV, the fact that I want one certainly has a bearing on my contentment, in the above sense. That is to say, if I want but do not have an HDTV, then I will not be motivated to remain in my current condition. Quite the opposite. I will be motivated to change my condition - in particular, I will be motivated to do what is necessary to obtain the TV. Though it may sound strange to say (without evident exaggeration) that I need consumer electronics, I think this is the sort of thing that Kant has in mind. To need a thing is simply to lack a thing and to be, in virtue of this lack, discontented with one's existence, that is, to be motivated to change one's condition so as to obtain the thing that one lacks.

If this is the right way to construe contentment, then it seems plausible to think that both finite and infinite beings can be contented with their existence. After all, a subject is contented with her existence when she is motivated to remain in her current condition. Since God lacks nothing and so needs nothing, this seems to describe his condition exactly. Finite beings, however, do not have it quite so easy. Our contentment is, as Kant says, 'a problem'. If a finite being is a needy being, and need is construed in terms of discontentment, then any finite being must thereby contend with the possibility of discontentment. This is not necessarily to say that such a being can never be contented with her existence. It is simply to say that if she is so contented, this is not because she, by nature, lacks nothing. It is because she has successfully obtained what she previously lacked. Such is the predicament of created beings, who are, as Kant says, 'always dependent with regard to what is required for a complete contentment with [their] condition' $(K p V, 5: 84)$.

It seems, then, as if contentment with one's existence is the kind of thing that can be intelligibly applied to both divine and human natures. Moreover, this broad applicability suggests that contentment is a good candidate for well-being, construed substantively. ${ }^{\text {Io }}$ Given this substantive construal, we can retain the genuine distinction between the 
three views of happiness under discussion: happiness as satisfaction of inclination, happiness as agreeableness, and happiness as well-being now, contentment. I noted above that the first two views are rather obviously different, and it should by now be equally obvious that the third view is different as well. Given these differences, can we make sense of why Kant would so easily associate them? I think we can.

\section{3}

The key to understanding the connection between Kant's three views of happiness is to see the first and second views as in some way falling under the third, that is, to see the satisfaction of inclination and feelings of agreeableness as things that bear on a subject's contentment. This assumes, of course, that the subject in question is finite. Again, God is contented but lacks inclination and feeling. I will return to divine contentment shortly, but I want to focus first on why human contentment and so happiness is bound up with these empirical elements, as Kant evidently thinks.

In order to see how the satisfaction of inclination and feelings of agreeableness bear on a finite subject's contentment, I must say something more about how Kant understands inclinations and agreeableness. To have an inclination is to be motivated to pursue an object on account of the agreeableness that one expects from the existence of that object $(G, 4: 4 \mathrm{I} 3$, $M S, 6: 2 \mathrm{I} 2, A, 7: 25 \mathrm{I})$. For example, if I find myself thinking about the nice, cold bottle of beer I will be able to drink after work, I may begin to anticipate the agreeableness I will experience at the first, delicious draught. This anticipation may then motivate me to undertake steps to obtain that beer, as soon as I am able to do so. Put this way, it is not hard to see that inclination and need will be closely connected. If I have an inclination for the beer, I will, in the absence of the beer, be motivated to change my condition so as to obtain it. I will, to that extent, have a need for it.

This suggests that achieving contentment with one's existence will necessarily involve attention to one's inclinations. What form this attention takes may differ depending on the circumstances. Kant clearly thinks that the standard case is one of satisfaction: if you have an inclination for a beer, the natural thing to do is to drink one. But in other cases the attention may be less straightforward, e.g. strategies of adaptation, suppression or, at the limit, extirpation. In all cases, however, something must be done if the subject is ever to be contented with her existence. For so long as she is inclined, she is in need; and so long as she is 
in need, she is discontented. This is why Kant says of inclinations that 'discontent always accompanies them' $(K p V, 5$ : I I 8$) .{ }^{\text {II }}$

What of agreeableness? As I noted above, inclinations are generated by anticipations of agreeableness. So it seems natural to think, as Kant does think, that, at least in normal cases, the satisfaction of inclination in fact produces agreeableness.

Despite the complicated and confusing surface of Kant's discussion of happiness, then, there seems to be an underlying structure. Most fundamentally, happiness is a kind of well-being and so contentment. The satisfaction of inclination and feelings of agreeableness are important to happiness but only because they bear on contentment. As finite beings, our contentment is hostage to our needs: we are completely contented only when our needs are met. Since our needs are connected to our inclinations, Kant associates happiness with the satisfaction of inclination. And since feelings of agreeableness are marks of the satisfaction of inclination, Kant associates happiness with agreeableness.

\section{4}

If this is the right way to think about happiness, then it should be obvious that the relation between happiness and well-being is more complicated than it at first appears. Strictly speaking, Kant does not identify happiness and well-being. Rather, he subsumes happiness under well-being. Happiness is a species of well-being. More specifically, it is the sensible species of well-being: the contentment that arises from inclinations and associated feelings.

But as the case of God clearly shows, happiness is not the only species of well-being that Kant admits. For recall, Kant attributes well-being to God, who lacks sensibility. Thus in addition to sensible well-being - in addition to happiness - Kant must also admit a non-sensible species of well-being: a contentment that arises not from inclination or feeling but from reason. Contrary to appearances, then, the Kantian account of well-being is not exhausted by the Kantian account of happiness. It also includes a non-sensible, intellectual species of well-being, exemplified by God.

Now one might immediately question the significance of this conclusion. For even if I am right that Kant allows God to live well without being happy, it does not follow that he allows us to do the same. After all, many things are true of God that are not true of us, especially as concerns the 
powers of pure reason. If I really want to show, then, that the Kantian account of human well-being is not exhausted by the Kantian account of happiness, I must give reason to think that Kant extends intellectual well-being beyond the bounds of divinity.

To see that he does, consider the following passage in the second Critique. After reviewing his argument that morality requires the moral law to determine the will directly, Kant raises the question: 'Have we not a word that does not denote enjoyment, as the word happiness does, but that nevertheless indicates a satisfaction with one's existence, an analogue of happiness that must necessarily accompany consciousness of virtue?' $(K p V$, 5: II $)$. Yes, he says, there is: 'This word is self-contentment (Selbstzufriedenheit)', ${ }^{\mathrm{I} 2}$ which contentment, Kant is clear, is an 'intellectual contentment', as opposed to the 'aesthetic contentment' that 'depends on the satisfaction of the inclinations' $(K p V, 5: \operatorname{II} 7-\mathrm{I} 8)$.

The importance of this passage is easy to overlook, since Kant speaks here only of contentment rather than well-being. But read in light of my argument that well-being just is contentment, its true meaning should be clear. Kant is not merely identifying self-contentment with intellectual contentment. He is also (and thereby) identifying self-contentment with intellectual well-being.

Moreover, shortly after this passage, Kant explicitly likens our self-contentment to God's blessedness. While he naturally denies that we can be blessed, since our contentment 'does not include complete independence from inclination and need', Kant does nonetheless claim that our self-contentment 'resembles' blessedness, insofar as it allows us to approximate, however imperfectly, the 'self-sufficiency that can be ascribed only to the supreme being' ( $K p V, 5:$ I I 8$)$. Kant's talk here of resemblance might suggest that all he intends to do is to analogize our self-contentment and God's blessedness and not to assert that they are instances of a single state of intellectual well-being. But Kant's fuller discussion of blessedness in his theology lectures provides evidence for the stronger claim. For example, he there identifies blessedness with the 'highest degree of self-contentment' and claims that if this self-contentment were to extend to our entire existence, it would be called blessedness' (VpR, 28: I089-90). These comments strongly suggest that God's blessedness is not different in kind from our self-contentment. The difference consists only in the fact that the former is a more perfect and complete instance of the kind than the latter. It seems, then, that intellectual well-being does not belong to God alone. It also belongs to us. 
Returning, then, to the taxonomy sketched above, I can be more specific about the identity of the relevant taxa. Well-being has two species: sensible contentment - happiness - and intellectual contentment - selfcontentment. Since God is a purely intellectual being, his well-being includes self-contentment alone, under the name 'blessedness'. And since humans are both sensible and intellectual beings, their well-being includes both happiness and self-contentment. We live well, in part, when we are happy, but we also live well, in part, when we are self-contented. ${ }^{13}$

I have arrived, then, at my first major conclusion. There is more to even human well-being than happiness. There is also self-contentment. My second major conclusion - that morality is intrinsically related to self-contentment and thereby to well-being - remains to be established.

\section{5}

Notice, though, that the course of my argument so far does at least push in this direction. For in the very passage in which Kant introduces self-contentment, he says of this state that it 'necessarily accompanies consciousness of virtue', understood as 'consciousness of freedom as an ability to follow the moral law with an unyielding disposition' ( $K p V, 5$ : I I7). Why, though, should morality be thought to give rise to contentment, and necessarily so? Kant's answer seems to be that, since morality involves 'mastery over one's inclinations', it necessarily allows for 'independence from them and so too from the discontent that always accompanies them' (KpV, 5: II 8$)$. This is a familiar enough thought relying on a familiar enough mechanism. Inclination breeds discontentment. Thus by diminishing the former, one thereby diminishes the latter. Indeed, in adverting to this mechanism, Kant seems to be aligning himself with a long and distinguished tradition in moral philosophy, according to which morality promises peace by delivering us from the tumult of inclination. ${ }^{\mathrm{I}}$

While this pacification story is certainly venerable and, I think, plausible, Kant's appropriation of it is nonetheless problematic. This is because, as we have seen, self-contentment is supposed to be a distinctively intellectual state. But if self-contentment is as I have just described it, it is hard to see how this could be so. Of course, it is the intellect that effects the relevant contentment by mastering inclination, but this does not imply that what is effected is thereby intellectual. After all, whether you achieve contentment by subduing your inclinations or by satisfying them, the quality of your condition remains a function of your sensible state - of the 
presence or, more relevantly, the absence of pathological desire. ${ }^{\mathrm{I}}{ }^{5}$ Thus, it seems, if self-contentment is truly intellectual, and if morality, the (practical) intellectual activity par excellence, is truly its source, then there must be a way to connect morality to contentment directly, without the mediation of inclination. The problem, though, is that Kant does not seem to countenance any such way. And if not, then it seems that my ambition to use self-contentment in order to forge an intrinsic link between morality and well-being must go unfulfilled.

Now I admit that Kant's second Critique comments about self-contentment do complicate my argument. That said, I do not think that these comments should settle the matter. For if we take seriously the account of divine contentment I sketched above, then we must admit that Kant is at least conflicted here. After all, it is clear enough that the second Critique characterization of self-contentment as a merely 'negative satisfaction', born of morality's mastery of inclination, does not apply easily to the case of God (KpV, 5: I I 7-I 8). Most obviously, since God has no inclinations, his self-contentment cannot be a matter of his mastering them. But neither can it be a matter of his being naturally free from inclination, since that would allow his intellect no role at all in generating his contentment, and so would render obscure the sense in which the resulting state could be intellectual, which of course it must be. The only contentment suited to God, it seems, is a contentment that has its source directly in his active intellect. Sensibility can have nothing to do with it.

Of course, many of Kant's remarks about God come from lectures, and it is understandable that one might wish to set them aside when they are at odds with more canonical works. Nevertheless, as philosophically engaged readers of Kant - in particular, as readers of Kant concerned about the connection between morality and well-being - I think it is worth our while to ask whether there might be more resources available to Kant than he himself realized, resources that are grounded in the canonical works but perhaps lead to non-canonical conclusions. And what we find, I think, is that there are. That is to say, Kant's own statements notwithstanding, I think there are credibly Kantian reasons to understand self-contentment as intellectual in a full-blooded sense: as a kind of contentment that necessarily accompanies virtue not because, through morality, we master inclination, but because, through morality, we engage in an intellectual activity that directly contents us, in more or less the way it does for God. My task in the remainder of this article is to explain how this could be so. 


\section{6}

Before I do this, however, there is one more problem I must address, since the barriers to such an account of self-contentment are not merely textual. They are philosophical too. For consider what this state must be. To be contented, I have claimed, is to be motivated to remain in one's current condition. Thus if the intellectual activity of morality gives rise to an intellectual contentment directly, this could only be because reason, in its moral employment, so motivates.

The problem with this proposal, though, is that it does not seem to be true. After all, moral reason prescribes activity, commanding us to pursue the apparently interminable tasks of perfecting ourselves, making others happy and, generally, giving rational and so moral form to a world that would otherwise lack it. But if this is right, then what Kant says about inclination and discontentment should apply equally well to reason. If (sensible) discontentment always accompanies inclination because inclination motivates one to change one's condition, then (intellectual) discontentment should always accompany reason too, and for the very same reason. The peace that morality gives with one hand, it takes away with the other; for reason, no less than inclination, is restless.

This is a disconcerting conclusion. But, at least in one way, it should not be entirely surprising. For if, again, contentment consists in the motivation to remain in one's current condition, then it really does seem that any activity whatsoever - and so, a fortiori, any intellectual and so moral activity - is necessarily bound up with discontentment. After all, to be discontented just is to be motivated to change one's condition. And what, one might reasonably ask, could it be to be active but to be so motivated?

Underlying this natural question, I surmise, is a natural picture of activity. ${ }^{\mathrm{I} 6}$ Consider, for example, the fact that ordinary action has a teleological and causal structure. We act for ends, and in acting for those ends, we seek to bring something about. But if so, then it is no mystery why activity seems bound up with discontentment. Whether I am acting to slake my thirst or to rectify injustice, I am striving to change my condition from one in which things are not as I want them to be to one in which they are. I am thus discontented with my existence and will remain so until I have achieved my end.

Moreover, once I have achieved my end, I will perforce cease to act. For if I am acting in order to bring something about, and I succeed in bringing it about, then there will be nothing left for me to do. Put another way, if 
action is in this way teleological and causal - if production is its sole point and purpose - then it seems, somewhat paradoxically, as if the very point of activity is inactivity. What activity, considered as such, aims at is its own cessation. Of course, I may have other ends to attend to and so other actions to undertake. But it will be just as true of these, as it was of my original action, that insofar as I am successful, I will no longer act at all. In bringing about the end of action, I bring about the end of action.

So long as this exclusively productive picture of activity remains in place, I think it will be very difficult to understand how morality could content us and so how self-contentment is so much as possible. But as this phrasing suggests, there is a way out: displace the productive picture. And this, I think, is exactly what Kant does in his account of moral activity. A Kantian agent can be at once morally active and intellectually contented because there is more to moral activity than simply bringing something about.

\section{7}

To see this, consider the fact that moral action issues from a good will. ${ }^{17}$ This is important because, though an agent of good will does aim to bring something about - all activity, for Kant, is to that extent productive - we do not evaluate her activity solely in light of this aim. As Kant says in Groundwork I, 'a good will is not good because of what it effects or accomplishes, because of its fitness to obtain some proposed end, but only because of its volition, that is, it is good in itself' $(G, 4: 394)$. Value here marks a success condition. Good willing is, in itself, successful. This is not, of course, to say that if I rush to your aid because I see that it would be good to do so, I will actually succeed in helping you. I may well not. I could trip, be knocked over by a rude pedestrian or simply take too long. But insofar as my action follows from a good will, it seems that I have acted well, and so successfully, simply in virtue of acting as I did.

Kant explains this remarkable feature of good willing by adverting to 'the principle of volition in accordance with which the action is done' $(G, 4$ : 400). That is, the good will is good not because of what it wills but because of how it wills - not because of the state of affairs to be produced but because of the way in which the agent represents that state of affairs, her practically effective conception of its value. Kant refines his account of this contrast in Groundwork II, when he introduces the distinction between hypothetical and categorical imperatives. Hypothetical imperatives pronounce actions good, but only as a means to something else. Categorical imperatives, on the other hand, pronounce actions good in 
themselves $(G, 4: 4 \mathrm{I} 4)$. The action is worth undertaking not because (or not only because) the action will produce some effect that the agent welcomes but because of some intrinsic feature of the action itself. The relation between this distinction and the good will should be obvious. For if the goodness of the good will does not depend on the effect but on the willing, then the agent of good will must be acting in accordance with a categorical rather than a hypothetical imperative. She must act as she does not simply because her action produces some desirable consequence. She must act as she does because her action is in itself good.

What this shows is that if there is such a thing as good willing, then the exclusively productive model of activity is at best incomplete. ${ }^{18}$ It cannot capture one of the fundamental features of good willed action, i.e. that such action is done for its own sake. Again, this is not to deny that in such cases the production of some state of affairs is an end. Surely it is, and insofar as the action does not produce the effect, it is, in one respect, a failure. But this is just to say that the success conditions of action are not simple but complex. There are, in fact, two distinct dimensions of success along which we evaluate such actions, since there are, so to speak, two ends at play here: the end that is the action and the end that is the effect to be produced by the action.

One important consequence of this revision of the success conditions of action is that we are no longer bound to think, as on the exclusively productive model, the paradoxical thought that the aim of activity, considered as such, is inactivity. When one thinks that the sole point of acting is to bring something about, it is very natural to think that success in activity can only mean the cessation of activity. If, in bringing something about, you have done everything you set out to do, then why would you still be doing anything? It would seem, quite literally, pointless. But on the more complicated model exemplified by action that issues from a good will, this is not necessarily the case. The point of the action is no longer exhausted by the production of the effect. Rather, the point is precisely to engage in the action, since the action is in itself good. In such cases, then, there is a dimension of success that is continuous with the action itself and does not merely await its completion. ${ }^{19}$ And so the paradox dissolves: the aim of activity is, at least in such cases, activity itself.

In liberating us from the exclusively productive model of activity, good willing also, I think, liberates us from the thought that activity and discontentment are necessarily bound together. For although the agent of 
good-willed action is still, in one sense, motivated to change her condition, there is another sense in which she is not motivated to change her condition at all. Rather, she is motivated to remain in her condition, since that condition, the condition of acting, is one that she wants to be in. That is to say, the agent of a good willed action wants to act as she is acting and is to that extent contented. This is (part of) what it is to be such an agent. ${ }^{20}$

Care is needed here, since the complexity of the success conditions of good willing can easily lead to confusion about the kind of contentment it allows. Consider, for example, the good-willed traveller who helps her fellow passenger put his suitcase in the overhead bin. She does what she does for its own sake and so wants to act as she is acting. But what is it exactly that she wants? What condition is it in which she is motivated to remain? One natural answer is that what she wants is to put the bag in the bin. Understood in the most straightforward way, however, this cannot be quite right. For if it were, then it would seem reasonable for the traveller to stretch out her action as long as possible, taking her sweet time in lifting the bag or pulling it out just as soon as she pushes it in. After all, if what she wants is to put the bag in the bin, then the bag's actually being in the bin is a threat to what she wants and so something she should resist. Surely, though, this is perverse.

But if the good-willed agent does not simply want to keep doing the very same action, in what sense, then, is she motivated to remain in her current condition? And, moreover, in what sense could this condition be a condition of acting? To answer these questions, we must attend more closely to the nature of good willing. While the generous traveller does, of course, want to put the bag in the bin, it is important to remember the description under which she wants to do this: she wants to do it because it is in itself good. This description matters because it makes clear that what the agent of good will wants is not simply to do discrete things like putting bags in bins, or telling the flight attendant that she is prepared to assume the responsibilities of sitting in an exit row. Rather, she wants to do all these discrete things because they are good. That is, qua good-willed agent, she wants to act as it is good to act. This may sound trivial but it is not. For how it is good to act can and does change. At one moment, it is good to put the bag in the bin. But once the bag is actually in the bin, then it is now good to do something else, e.g. to sit down and clear the aisle so that other people can move through. Properly speaking, then, the condition the good-willed agent is motivated to remain in is nothing but the condition of good willing itself, and she remains in this 
condition by undertaking those actions that are in themselves good. Considered individually, such actions may stop, but good willing goes on.

It is in this sense, then, that the agent of good-willed action wants to act as she is acting and is to that extent contented. She wants to act as it is good to act, whatever that turns out to be. ${ }^{2 \mathrm{I}}$ On the exclusively productive model, by contrast, what the agent wants is not to act - not really. What she wants is the existence of a certain state of affairs, and her action is simply a means to that end. This is why it makes perfect sense for her to cease acting after she has brought about that state of affairs, or, perhaps, never to act at all, if she were self-sufficient and so in need of nothing.

Thus it seems that introducing this distinction in action requires introducing a correlative distinction in contentment. On the one hand, there is a kind of action whose end is entirely beyond itself. The kind of contentment that seems suited to this kind of action is the contentment of rest: a subject is motivated to remain in her current condition, and thus contented, because she wants to do nothing. On the other hand, there is a kind of action whose end is itself. The kind of contentment that seems suited to this kind of action is the contentment of activity: a subject is motivated to remain in her current condition, and thus contented, because she wants do what she is doing, i.e. acting as it is good to act. So long as one thinks of action only according to the exclusively productive model, the first kind of contentment will seem the only one available and the tension between contentment and activity will seem inescapable. But once one acknowledges action that is not entirely productive, action such as that involved in good willing, the second kind of contentment seems available too. ${ }^{22}$

It is this availability that allows us, at last, to understand how self-contentment is possible, not merely in the attenuated sense of being caused by moral reason's mastery of inclination but in the full-blooded sense of being generated directly by morally rational activity itself. As I noted in $\$ 6$, it is not easy to see how there could be such a state, since it is not easy to see how reason, in its moral employment, could motivate an agent to remain in her current condition rather than to change it. But, as I have just argued, this difficulty should dissipate once one recognizes that moral action issues from a good will and so is done for its own sake. A good-willed agent can be motivated to remain in her current condition, and can thus be self-contented, because, as a good-willed agent, she wants to act as she is acting. 
I am now in a position to bring my argument to a close. Recall that my aim has been to show that morality and well-being can be intrinsically related in a Kantian framework. It has seemed otherwise because it has seemed obvious that the Kantian account of well-being is exhausted by the Kantian account of happiness, in which case morality's role in a life well led is entirely dependent on its sensible influence. But what seems obvious is false. There are good reasons to think that the Kantian account of well-being is not exhausted by the Kantian account of happiness. Well-being is a genus with two species: one sensible - happiness - and one intellectual - self-contentment. Thus while morality, as rational activity, can only be extrinsically related to happiness, it can be intrinsically related to self-contentment and thereby to well-being.

So far, this is just a possibility proof. And, as I explained above, there are both textual and philosophical reasons to worry whether what is possible is also actual. But, I have argued, these worries can be addressed by drawing connections that are available to Kant but which Kant himself does not draw. Though Kant may in fact think of self-contentment as a merely negative satisfaction that results from mastery of inclination, he need not think this. Rather, given his account of moral activity as self-sustaining, it is open to him, and so to his followers, to regard self-contentment more positively, as the active contentment that consists in an agent's acting as she wants to act because it is good to do so. Moreover, since this motivational commitment is part of the nature of moral activity, it follows that moral activity is not merely necessarily related to self-contentment. It is intrinsically related to self-contentment and thereby to well-being.

This is a limited conclusion but an important one. It is limited because it concerns morality's relation to just one aspect of our well-being, selfcontentment. It says nothing of the other, happiness. ${ }^{23}$ It is important, however, because it allows the Kantian to say something that it seemed she could not, i.e. that morality is in and of itself a source of well-being, something that makes a life go well. Again, this is not to say that morality is sufficient for well-being, in the sense of providing us everything we need for a life well led. Something like this may be true for God, whose only contentment is self-contentment, but it is not true for us. Since we remain 'always dependent with regard to what is required for a complete contentment with [our] condition', we cannot do without happiness, however self-contented we may be $(K p V, 5: 84) \cdot{ }^{24}$ Nevertheless, in acting morally, in being self-contented, we do partake, however imperfectly, in 


\section{the independent life of the divine. And so, whatever other benefits and burdens morality might bring, it is also and truly its own reward. ${ }^{25}$}

\section{Notes}

I On this way of thinking, we may - and perhaps even must - hope for a future happiness, insofar as we make ourselves worthy of it. That said, realizing this hope is beyond our power as mere mortals. Hope shades into faith, ethics into religion.

2 This is a dominant theme in Barbara Herman's interpretation. See Herman I993a, I993b, 2007a, 2007b. See also Baron I999 and Korsgaard 1996.

3 I use the following abbreviations for and translations of Kant's works: Critique of Pure Reason $=K r V$ (Kant 1998); Critique of Practical Reason $=K p V$ (Kant 1997a); Critique of the Power of Judgment $=K U$ (Kant I996a); Groundwork of the Metaphysics of Morals = G (Kant I997b); The Metaphysics of Morals = MS (Kant I996b); Anthropology from a Pragmatic Point of View = A (Kant 2006); Lectures on Metaphysics = VM (1997c); Lectures on the Philosophical Doctrine of Religion $=\mathrm{VpR}$ (Kant I996d). I cite the first Critique with the standard 'A/B' pagination and the other works according to the Academy edition pagination, which is included in the volumes of translations utilized.

4 I assume throughout that Kant's concept of well-being (Wobl) is restricted, as he says, to the worth of one's condition rather than the worth of one's person, to being well (Woblbefinden) rather than acting well (Woblverhalten) (KpV, 5: 60-I, 88; G, 4: 442, 449-50). It is not obvious how to understand these contrasts, but acknowledging Kant's reliance on them is important, since (i) it makes clear that his concept of well-being is not as general as it might at first appear, and (ii) it allows for the possibility of a concept of well-being that is, in the present context, the exact opposite of Kant's: one that does concern personality and action. Indeed, one might think that such a concept is not merely possible; it is actual. For example, it seems at the fore in ancient discussions of eudaimonia, understood in broadly perfectionist terms, such as living - in the sense of acting - well, performing one's function, realizing one's nature, etc. Of course, such thoughts are not foreign to Kant, as is evident from his frequent discussion of our vocation as rational beings, of the conditions under which we are true to our proper selves, etc. $(K p V, 5: 87, G, 4: 458)$. But, notably, these thoughts do not belong to his discussion of well-being. Rather, they belong to his discussion of morality. If this is right, then we must be very careful in understanding Kant's relation to other figures and philosophies. We cannot assume that key terms are univocal, and so we cannot assume that apparent conflicts are genuine. I hope to expand on these points in future work.

5 Notably, God does have pleasures - just not sensible ones (VpR, 28: 1059-60). See Elizondo 20I4 for further discussion of non-sensible pleasures.

6 To be clear, it does not follow from the fact that we lack cognition of God that we may think of him however we wish. Thus, though our thoughts about God are, in a certain sense, merely speculative, Kant thinks that such thoughts can nonetheless constitute genuine understanding of the concept of God. For discussion of Kant's philosophical theology, though with a more metaphysical than psychological emphasis, see Wood 1978.

7 For other mentions of satisfaction (Zufriedenheit) in the context of happiness, see G, 4 : 393, MS, 6: 387 and VpR, 28: 1060.

8 This is how others translate the term - e.g. Guyer and Matthews in Kant I996a, Wood and di Giovanni in Kant I996c, and Ameriks and Naragon in Kant I997c - and it is how Gregor herself translates it in other places. Hereafter, I will amend Gregor's translations, 
as necessary, so that Zufriedenheit and its cognates are always translated by 'contentment' and its cognates.

9 Indeed, I think this notion is dominant throughout Kant's work, explaining why he so readily associates inclination, feeling and need $(K p V, 5: 26$, II $8 ; G, 4: 4$ I 8,428$)$. I discuss these associations in $\$_{3}$.

Io One might be sceptical of this suggestion on the grounds that contentment itself is a formal notion, and so is no candidate at all - never mind a good one - for well-being, construed substantively. I think such scepticism is misplaced. If contentment were formal, in a way that would spell trouble for my argument, then we should expect the identification of wellbeing and contentment to be trivial. But this is not so. It is clearly a substantive (and controversial) claim that what makes an agent's life go well for her is her being motivated to remain in her current condition. Of course, it is true that the conditions of contentment are left open by the account of contentment presented here: what makes one agent contented may not make another agent contented. But this does not make contentment formal. Or, at least, it does not make it any more formal than the satisfaction of inclinations, which similarly leaves it open which inclinations a given agent has.

I I My point here is simply to connect inclination to contentment. It is not to give a full account of this connection - what to say, for example, about inclinations that we do not want to satisfy. One thing, however, is worth noting. If all there were to contentment were the removal of need, then it would seem that, Kant's emphasis on satisfaction notwithstanding, there would be no principled reason to prefer satisfying the inclinations to extirpating them. Both strategies would be, so to speak, different paths to the same destination. The only basis for deciding between them, then, would be how easily they get us where we are going.

I2 Gregor translates Selbstzufriedenheit as 'contentment with oneself'. I prefer the simpler and more literal 'self-contentment'. In this I follow Wood and di Giovanni in Kant I996c.

I3 Victoria Wike 1994 similarly argues that there are two kinds of well-being in Kant, one sensible and one intellectual. Since her primary interest, however, is in sensible well-being, in happiness, she does not devote much attention to intellectual well-being, to self-contentment; and to the extent that she does, she seems to take for granted the negative characterization of self-contentment that I go on to discuss and then challenge.

I4 This alignment is clear from Kant's frequent references in these passages to the Epicureans and Stoics.

I5 See again my discussion of inclination and contentment in $\$ 3$.

I6 This natural picture is also reflected in a number of philosophical accounts of action, which connect motivation with some privative condition: dissatisfaction, uneasiness, suffering, etc. See, for example, Hobbes 1994: 34, 57; Locke 1979: 25I-2; and Schopenhauer 1969: 196.

I7 Though the following exposition of good willing is adequate for present purposes, I pass over many important details. See Elizondo 2013 for further discussion of the will and what makes it good.

I 8 Christine Korsgaard has also recently emphasized the way in which Kant rejects an exclusively productive model of activity, of the sort she attributes to Mill, in favour of a more Aristotelian alternative (Korsgaard 2009: 8-I 8). She does not, however, connect his view of activity to his view of well-being.

I9 Or, one might say, the action is, in one respect, complete throughout rather than merely brought to completion. This seems to be the way Aristotle thinks of energeia, of which virtuous activity is a prime example (Aristotle I999: I 57-8; I I74a I3-bI4). I mean my Kant to be quite close to Aristotle in this respect. 
20 To be clear, though the good-willed agent is contented in acting as she does, she does not act as she does because she seeks contentment. She acts as she does because it is in itself good - and that is why she is contented. Thus my claim here does not threaten the purity of moral motivation. On the contrary, it presupposes it.

2 I One might ask here whether Kant's famous scepticism about self-knowledge creates a problem for the very close connection I am trying to forge between good willing and contentment. I do not think it does. My argument turns on the claim that good willing is a kind of activity that constitutively involves certain motivational commitments, e.g. wanting to act as one is acting because it is good to do so. That we may think we are involved in this activity when we are not does not itself call this characterization into question. Indeed, I think this kind of distinction between the epistemic and metaphysical conditions of activity is exactly the sort of thing Kant has in mind at the beginning of Groundwork II, where he offers one of his most famous statements about our psychological opacity $(G, 4: 406-7)$. That experience furnishes no certainty that we have ever acted from duty is no reason to doubt that good willing constitutively involves motivation of this kind.

22 It is worth noting that this distinction between kinds of contentment can be plausibly mapped onto the distinction between our rational, or 'higher', and sensible, or 'lower', faculties. What the higher/lower distinction is supposed to track in all of these cases is the activity or passivity of the subject with respect to the exercise of her faculties. On the practical side, the distinction mainly tracks the difference between motivation through rational concepts, i.e. volition, and motivation through inclination and feeling. If there is, then, a kind of contentment that is tied to rational nature, to the will, we should expect it to be, like rational nature itself, active. If there is a kind of contentment that is tied to sensible nature, to inclination and feeling, we should expect it to be, like sensible nature itself, passive. And this, it seems, is exactly what we find in the distinction between the two kinds of contentment considered above.

23 Though recall, as I noted in my introduction, that I am largely in agreement with the good work that has been done recently on the relation between morality and happiness. To this extent, my position is better thought of as a friendly supplement to this work rather than an alternative to it.

24 Interestingly, this seems to be one of Kant's main complaints against the Stoics. They in effect cast their sage as a god, as an agent whose well-being consists completely in self-contentment and not at all in happiness ( $K p V, 5:$ I 27$)$.

25 For helpful discussion of issues relevant to this article, I thank Tyler Burge, John Carriero, Jorah Dannenberg, Michael Della Rocca, Jay Elliott, Barbara Herman, Yannig Luthra, John McCumber, Stephen White and members of the UCLA Ethics Writing Workshop. I also thank two anonymous reviewers for this journal for their comments.

\section{References}

Aristotle (I999) Nicomachean Ethics, trans. and ed. Terence Irwin. Indianapolis, IN: Hackett Publishing Co.

Baron, Marcia (I999) Kantian Ethics (Almost) without Apology. Ithaca, NY: Cornell University Press.

Elizondo, E. Sonny (2013) 'Reason in its Practical Application'. Philosopher's Imprint, I3 (2I), I-I7.

- (20I4) 'More than a Feeling'. Canadian Journal of Philosophy, 44(3-4), 425-42.

Herman, Barbara (I993a) 'Agency, Attachment, and Difference'. In Barbara Herman, The Practice of Moral Judgment (Cambridge, MA: Harvard University Press, I993), pp. I84-207. 
_ (I993b) 'Integrity and Impartiality'. In Barbara Herman, The Practice of Moral Judgment (Cambridge, MA: Harvard University Press, I993), pp. 23-44.

— (2007a) 'Obligatory Ends'. In Barbara Herman, Moral Literacy (Cambridge, MA: Harvard University Press, 2007), pp. 254-75.

(2007b) 'The Scope of Moral Requirement'. In Barbara Herman, Moral Literacy (Cambridge, MA: Harvard University Press, 2007), pp. 203-29.

Hobbes, Thomas (1994) Leviathan, ed. Edwin Curely. Indianapolis, IN: Hackett Publishing Co.

Kant, Immanuel (I996a) Critique of the Power of Judgment, trans. and ed. Eric Matthews and Paul Guyer. Cambridge: Cambridge University Press.

— (1996b) Metaphysics of Morals, trans. and ed. Mary Gregor. Cambridge: Cambridge University Press.

- (1996c) Religion and Rational Theology, trans. and ed. George Di Giovanni and Allen W. Wood. Cambridge: Cambridge University Press.

- (1996d) Lectures on the Philosophical Doctrine of Religion. In Kant 1996c.

- (I997a) Critique of Practical Reason, trans. and ed. Mary Gregor. Cambridge: Cambridge University Press.

(1997b) Groundwork of the Metaphysics of Morals, trans. and ed. Mary Gregor. Cambridge: Cambridge University Press.

- (1997c) Lectures on Metaphysics, trans. and ed. Karl Ameriks and Steven Naragon. Cambridge: Cambridge University Press.

- (1998) Critique of Pure Reason, trans. and ed. Paul Guyer and Allen W. Wood. Cambridge: Cambridge University Press.

- (2006) Anthropology from a Pragmatic Point of View, trans. and ed. Robert B. Louden. Cambridge: Cambridge University Press.

Korsgaard, Christine (1996) The Sources of Normativity. Cambridge: Cambridge University Press.

— (2009) Self-Constitution: Agency, Identity, and Integrity. Oxford: Oxford University Press.

Locke, John (1979) An Essay Concerning Human Understanding, ed. Peter H. Nidditch. Oxford: Oxford University Press.

Schopenhauer, Arthur (1969) The World as Will and Representation, vol. I, trans. E. J. F. Payne. New York: Dover Publications.

Wike, Victoria S. (1994) Kant on Happiness in Ethics. Albany, NY: State University of New York Press.

Wood, Allen W. (1978) Kant's Rational Theology. Ithaca, NY: Cornell University Press. 